\title{
Recovery of the red-finned blue-eye: an endangered fish from springs of the Great Artesian Basin
}

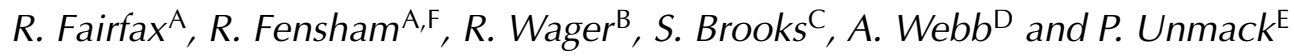 \\ ${ }^{\text {A } Q u e e n s l a n d ~ H e r b a r i u m, ~ E n v i r o n m e n t a l ~ P r o t e c t i o n ~ A g e n c y, ~ M t ~ C o o t-t h a ~ R o a d, ~ T o o w o n g, ~}$ \\ Qld 4066, Australia. \\ ${ }^{B}$ CRFH Pty Ltd, PO Box 106, Esk, Qld 4321, Australia. \\ ${ }^{C}$ Department of Primary Industries and Fisheries, GPO Box 46, Brisbane, Qld 4001, Australia. \\ DSchool of Tropical Biology, James Cook University, Douglas, Qld 4811, Australia. \\ EIntegrative Biology, 401 WIDB, Brigham Young University, Provo, UT 84602, USA. \\ ${ }^{\mathrm{F} C}$ Corresponding author. Email: rod.fensham@epa.qld.gov.au
}

\begin{abstract}
The red-finned blue-eye (Scaturiginichthys vermeilipinnis) is endemic to a single complex of springs emanating from the Great Artesian Basin, Australia. The species has been recorded as naturally occurring in eight separate very shallow (generally $<20 \mathrm{~mm}$ ) springs, with a combined wetland area of $\sim 0.3$ ha. Since its discovery in 1990 , five red-finned blue-eye (RFBE) populations have been lost and subsequent colonisation has occurred in two spring wetlands. Current population size is estimated at $<3000$ individuals. Artesian bores have reduced aquifer pressure, standing water levels and spring-flows in the district. There is evidence of spatial separation within the spring pools where RFBE and the introduced fish gambusia (Gambusia holbrooki) co-occur, although both species are forced together when seasonal extremes affect spring size and water temperature. Gambusia was present in four of the five springs where RFBE populations have been lost. Four out of the five remaining subpopulations of RFBE are Gambusia free. Circumstantial evidence suggests that gambusia is a major threat to red-finned blue-eyes. The impact of Gambusia is probably exacerbated by domestic stock (cattle and sheep), feral goats and pigs that utilise the springs and can negatively affect water quality and flow patterns. Three attempts to translocate RFBE to apparently suitable springs elsewhere within the complex have failed. Opportunities to mitigate threats are discussed, along with directions for future research to improve management of this extremely threatened fish and habitat.
\end{abstract}

\section{Introduction}

The Great Artesian Basin (GAB) is a vast groundwater resource that once sustained $\sim 500$ complexes of permanent springs. These springs provide a limited and very specialised habitat for a suite of endemic organisms, including plants (Fensham and Fairfax 2003), molluscs (e.g. Ponder and Clark 1990) and other macroinvertebrates (Ponder 2004). Eight described fish species are considered endemic to GAB spring wetlands, and these represent a quarter of the native freshwater fish fauna naturally occurring in the Lake Eyre catchment $\left(1.3\right.$ million $\left.\mathrm{km}^{2}\right)$ of inland Australia (Wager and Unmack 2000).

Thousands of bores have been drilled to tap the GAB aquifer since 1878 , primarily to provide permanent potable water for pastoral purposes. Historical comparisons clearly demonstrate that aquifer pressure decline has dramatically decreased flows from bores and springs in discharge areas of the GAB (e.g. Habermehl 2001; Fairfax and Fensham 2002). For these areas in Queensland, Fensham and Fairfax (2003) indicate that $61 \%$ of 163 spring complexes are completely inactive and another $19 \%$ include springs that are inactive. Remaining spring wetlands are threatened by mechanical interference, domestic stock and feral animal impacts, and introduced aquatic species (Fensham and Fairfax 2003). The presence of the exotic fish gambusia (Gambusia holbrooki) throughout many of the GAB springs poses a particularly acute threat to the endemic fish.
Gambusia spp. have been implicated in the loss of fish from North American springs (e.g. Meffe 1983; Miller et al. 1989; Minckley 1999) and are suspected to negatively affect various species in the Mediterranean region (Crivelli 1995; Elvira 1995). Gambusia have also been implicated in the decline of some Australian freshwater fish populations including blue-eyes (see examples in Arthington et al. 1983 and Lloyd et al. 1986), and have negatively affected body size, bodyweight and gonad development of Pseudomugil signifer experimentally (Howe et al. 1997). Circumstantial evidence implicates Gambusia in population declines and range restrictions of Galaxiella pusilla (Unmack and Paras 1995), reduced reproductive success of Maccullochella peelii peelii and Macquaria ambigua (Pierce et al. 2004), declines in Nannoperca australis (see Lloyd 1984) and other native fish species (Morgan et al. 2004). The diet of Gambusia and Australian fish species can overlap (e.g. Arthington and Marshall 1999), and studies have shown substantial negative impacts of Gambusia on populations of insects, plankton, crustaceans and molluscs (see Arthington 1991).

While the threats to the GAB springs are well known in general terms there have been no detailed assessments for individual species. The subject of this paper, the red-finned blue-eye (RFBE), is endemic to one GAB spring complex, Edgbaston Springs in central Queensland. The RFBE is listed as critically 
endangered under the IUCN Red List of threatened species (IUCN 2006). This paper provides data on groundwater trends, the habitat characteristics of RFBE, subpopulation trends of both RFBE and Gambusia over 16 years, some detailed data on temporal and spatial patterns of occupation for RFBE in spring pools with and without Gambusia, and the fate of captive-breeding attempts. Potential threats are identified, suggestions for management provided, and recommendations for research that will inform the mitigation of threatening processes outlined.

\section{General species description}

The RFBE (Fig. 1) was discovered in 1990 and described by Ivantsoff et al. (1991). It is Australia's smallest freshwater fish, reaching a length of $30 \mathrm{~mm}$. Scaturiginichthys is a monotypic genus in the Pseudomugilidae. Species from this family are small fish, typically inhabit lotic freshwater, are nektonic and omnivorous. RFBE have been seen eating from the substrate, vegetation and water column. Both sexes of all pseudomugilids usually have blue irises and iridescent body colouring, although the fins of adult male Scaturiginichthys are generally larger than those of the females and tinged with bright vermilion when in reproductive mode. External morphology separating RFBE from other blue-eyes include a narrow rounded caudal fin, higher insertion of pectoral fins and frequent absence of ventral fins.

Males may defend a variable individual space as opposed to a fixed territory and courtship displays have been seen during every month. Fry have also been seen during every month and greatest numbers of both adults and fry have been seen in April.

Observations from captive populations indicate that the average RFBE lifespan seems to be $\sim 18$ months or less, with vigour, colour and straightness of spine decreasing with age. The longest a RFBE survived in captivity was $\sim 30$ months (R. Robinson, pers. comm. 2005). Females can breed more or less continuously between 4 and 15 months of age, and within that time have at least a 4-6-week period of laying, on average, 1-3 (maximum 7) eggs day ${ }^{-1}$ (e.g. Tappin 1995a). Eggs are opaque and very large for the size of the fish $(\sim 1.5 \mathrm{~mm}$ diameter) with filaments that attach to vegetation or substrate. Fry hatch after 1-2 weeks, with egg hatching rates in captivity documented to be at least 44\% (Tappin 1995a) and a little

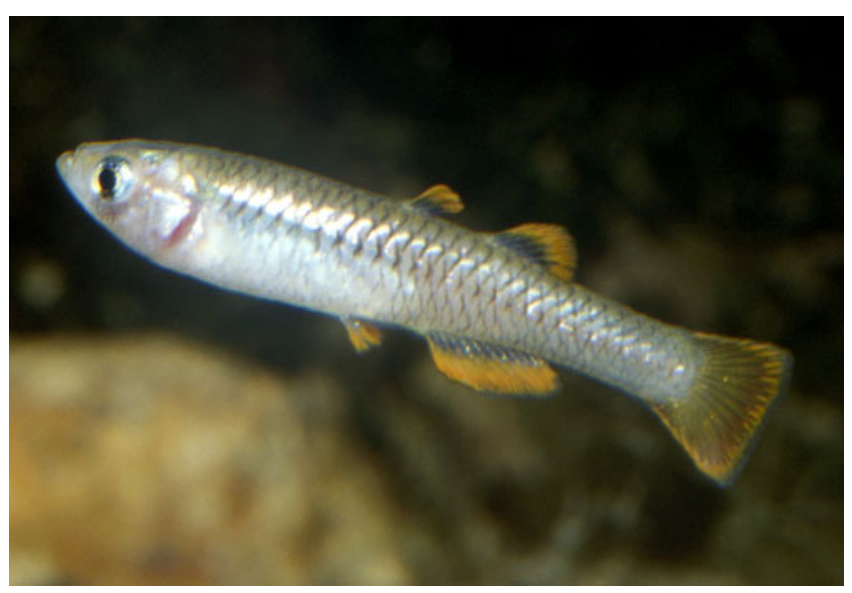

Fig. 1. A male RFBE (Scaturiginichthys vermeilipinnis). Photo courtesy of G. Schmida. over $60 \%$ (Robinson 2004). Individuals can reach half adult size in 6-10 weeks.

\section{Methods \\ Aquifer trends}

The status of springs in the vicinity of Edgbaston was assessed using an updated version of the database described by Fensham and Fairfax (2003). Records of bore flows, standing water levels (the pressure surface of the aquifer) and capping and piping status from the region of Edgbaston Springs were collated from Queensland Department of Natural Resources and Water records.

\section{Subpopulation and habitat monitoring}

Population estimates for a subset of the springs were documented by Unmack (1992). The entire spring complex was subsequently monitored every year until 1997, then again in 2005 and 2006. Spring names (e.g. NW10) follow Wager (1998). Accurate assessments of population size can be difficult owing to the small size of the fish and vegetation cover and these difficulties are amplified in larger springs. To this end, RFBE populations since 1992 have been largely estimated on the basis of counts of individuals in small areas multiplied by area of habitat. However, despite possible discrepancies between surveyors and survey conditions, the limited habitat area, depth, cover and high visibility permit a credible relative assessment through time. All springs in the complex have been surveyed for RFBE. Some permanent and semipermanent water bodies, including bore drains, have also been sampled.

During these surveys, information was also collected on water temperature and the presence of Gambusia. In some cases Gambusia abundance was estimated using the same technique as for RFBE.

\section{Water chemistry}

Water chemistry attributes were measured for 23 springs, including all known to have contained RFBE, following procedures in Clesceri et al. (1998). Data were combined from Fensham and Fairfax (2003) and Wager (1994). In some situations extreme values reflect a disturbed spring, e.g. the maximum $\mathrm{NH}_{4}$ value is associated with recent stock use of that spring. For this reason the extremes, median and mean are all presented. An ANOVA compared water-chemistry attributes between springs naturally containing RFBE with those in which RFBE have never been recorded.

\section{Habitat relations of RFBE and Gambusia}

To assess possible impacts of stock, pigs and Gambusia on RFBE populations, one spring with RFBE and Gambusia (NE60) and one spring with RFBE without Gambusia (NW30) were selected and monitored before fencing. Transects were established every $2 \mathrm{~m}$ across the width of springs for the entire length of wetland area. Every metre point was recorded as either dry ground, wet ground, or covered by the plants Pennisetum alopecurioides, Sporobolus pamelae or other vegetation. Evidence of grazing, prints, faeces and carcasses were also recorded and assigned to cattle, sheep or pig where possible. On each transect the edges of the wetland, defined as surface water, were mapped to the nearest $0.1 \mathrm{~m}$. Fish species present in the 
$2-\mathrm{m}^{2}$ cells along the transects were recorded, along with their abundance in $90 \%$ of cells where present. Water depth to the nearest $5 \mathrm{~mm}$ was recorded in $\sim 93 \%$ of cells containing fish, and water temperature to the nearest $0.5^{\circ} \mathrm{C}$ recorded in almost $60 \%$ of cells occupied by fish. Temperature was also recorded in more than twice as many cells again throughout the wetlands, and depth for $92 \%$ of the total wetland cells. These measurements were made for each spring on consecutive days between 0800 and 1300 hours in August and November 1993, plus January, April and June 1994. Other observations on springs, RFBE behaviour and interactions with Gambusia were made throughout these monitoring periods. The study sites were fenced in May 1997, but the fences have since fallen into disrepair and the monitoring of these sites has not been repeated.

Water depth and water temperature for the two monitored springs is graphically presented according to spring, season, fish species, juveniles and adults. The relationship between water depth and occurrence of juvenile RFBE, adult RFBE and adult Gambusia throughout the five sampling times (seasons) was analysed using separate ANOVA tests. These compared the occupied depth for: (1) juvenile RFBE according to Gambusia presence $\times$ season (all combinations were available in only three seasons); (2) adult RFBE according to Gambusia presence $\times$ season; and (3) adult fish according to species $\times$ season within the spring where both RFBE and Gambusia co-occur. The results can be interpreted only as indicative because this analysis necessarily involves multiple comparisons, and the two springs have inherent differences. Water temperature of the two springs is substantially different (see below) and was not further analysed.

\section{Captive breeding}

Over half the 34 people known to have kept the RFBE in captivity (representing $\sim 40$ breeding attempts) were contacted and interviewed with the intention of elucidating successful techniques for maintaining and breeding the species in captivity. Record keeping was generally scant and observations inconsistent between fish keepers. However, the exercise was useful for determining the extent of fish harvesting from the wild populations, some aspects of RFBE biology and the current status of captive populations.

\section{Results and discussion}

\section{Aquifer trends}

Edgbaston Springs are classified as 'discharge' springs within the Barcaldine supergroup (Fensham and Fairfax 2003). Five of the 25 spring complexes making up this group are completely inactive and 15 include both active and inactive springs. It is unknown whether inactive springs in the district formerly contained populations of RFBE, although examples of aquifer drawdown resulting in the loss of populations of GAB spring-endemic species are known from elsewhere (McLaren et al. 1986; Fairfax and Fensham 2003; Kinhill Engineers Pty Ltd 1997).

Several springs within the Edgbaston complex are no longer active, and two of these have had bores sunk directly on them. All bores within $10 \mathrm{~km}$ of Edgbaston (Fig. 2) show declines in both flow and standing water level and suggest that aquifer pressure is continuing to decline. Multiple measurements over time were not made for some artesian bores that have since become subartesian (standing water level is below the ground surface). Of the 131 registered pastoral bores within $70 \mathrm{~km}$ of Edgbaston Springs, 79 are equipped so that flows could be regulated and piped, but the balance flows into open bore drains where most water is lost to evaporation. A recent program of capping and piping flowing bores throughout the Basin (GABCC 2000) should provide improvements to groundwater pressure.

\section{Nature of the springs}

Edgbaston Springs is situated in central Queensland in the upper reaches of the Thomson River, which is part of the Lake Eyre catchment. Surface streams in this area are ephemeral although some waterholes may persist between rainfall events. Groundwater is supplied from thinly confined Jurassic sandstones.

The Edgbaston Springs complex currently contains 51 active springs scattered within an area of $\sim 50 \mathrm{~km}^{2}$. The highest spring is $7 \mathrm{~m}$ above the lowest. Current (2006) combined total wetland area is $\sim 2.4$ ha; the largest individual wetland is $\sim 0.4$ ha, and total wetland area of the five springs currently supporting RFBE is $\sim 0.3$ ha. Fig. 3 illustrates a typical spring providing RFBE habitat. Other water bodies in the catchment do not appear to support the species.

All springs are considered permanent, although some unexplained changes in flows have occurred, such as the temporary drying out of spring SW50 during summer 1993-94 (R. Wager, pers. obs.). Spring wetlands enlarge after rainfall events, when soils containing the spring pools are saturated. Average January maximum air temperature at Barcaldine, the nearest rainfall station is $35.6^{\circ} \mathrm{C}$ (maximum $45^{\circ} \mathrm{C}, 85$ years of record). Average pan evaporation is $10.7 \mathrm{~mm} \mathrm{day}^{-1}$ in January and $4 \mathrm{~mm} \mathrm{day}^{-1}$ in June. The surface area of two springs has been measured to be about four times smaller in January than June (Fig. 4). Average July minimum air temperature at Barcaldine is $7.8^{\circ} \mathrm{C}$ with subzero minima recorded. There can be considerable difference in the median and range of daytime water temperatures between springs (Fig. 5). One of the springs for which detailed measurements are available (NW30) exhibits fairly narrow daytime temperature range through the year $\left(20-33^{\circ} \mathrm{C}\right)$, while NE60 has

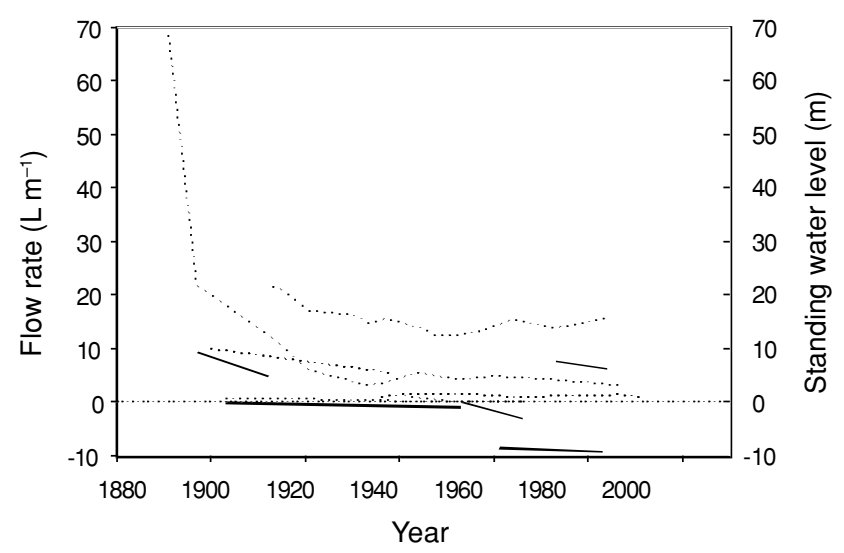

Fig. 2. Flow ( $\mathrm{L} \mathrm{s}^{-1}$, dashed lines) over time for the eight bores within $10 \mathrm{~km}$ of Edgbaston Springs for which information is available. Standing water-level measurements over time (metres, thick lines) exist for four of these bores, plus one subartesian bore. 
substantial seasonal variation $\left(10-38.5^{\circ} \mathrm{C}\right)$. Water temperature in the tail of one spring (NE60) has varied between $3^{\circ} \mathrm{C}$ and $30^{\circ} \mathrm{C}$ in a $24-\mathrm{h}$ period.

Substrate varies in clay and sand content and travertine is associated with several of the larger springs. Soil $\mathrm{pH}$ around spring margins varies from 7.14 to 10.98 (20 samples). Water in springs not disturbed by excavation is clear and can be up to $50 \mathrm{~cm}$ deep around discharge vents, although in most springs depth is less than $5 \mathrm{~cm}$. Water $\mathrm{pH}$ is moderately basic (average 7.93) with a high total alkalinity and dissolved $\mathrm{CO}_{2}$. The water is soft (low calcium and magnesium ions) and high in total dissolved solids and sodium (Table 1). The ANOVA found no significant difference (all $P<0.05$ ) between water chemistry attributes of Table 1 for springs in which RFBE are naturally present or absent (Table 2).

Generally for any given spring about half the wetland area has vegetation cover. Sedges and tussock grasses such as Sporobolus pamelae and Cyperus laevigatus are common although some areas can be dominated by dense mats of short herbs including Myriophyllum artesium and Eriocaulon carsonii. Thickets of a native tree (Melaleuca bracteata) and the exotic tree Acacia nilotica occupy the landscape around the springs, but generally wetlands are in full sun.

The RFBE, the Edgbaston goby (Chlamydogobius squamigenus), eleven molluscs, several undescribed crustaceans, a flatworm, a dragonfly, three undescribed plant species and at least one wolf spider are completely endemic to Edgbaston Springs (R. Fensham, R. Fairfax and W. Ponder, unpubl. data), making them the most significant springs for biodiversity conservation in the entire GAB. Cattle have been in the district for $\sim 30$ years, sheep for 130 years and pigs for at least 90 years. Feral goats also regularly utilise the springs.

\section{Trends in RFBE subpopulations}

Throughout the monitoring history RFBE have been recorded as naturally occurring in eight separate springs. The entire population appears to generally contain 3000-5000 individuals although the latest population estimate is less than 3000

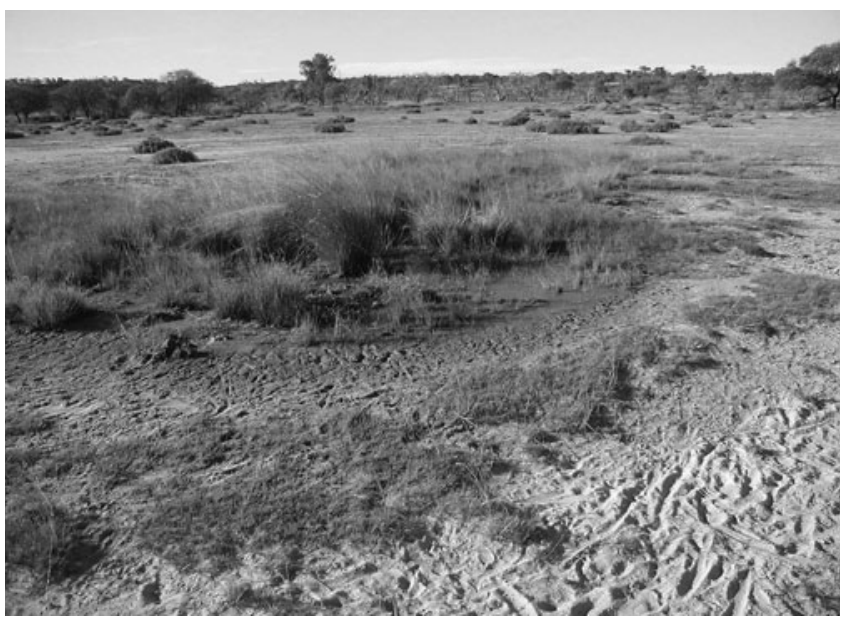

Fig. 3. Typical RFBE habitat (spring NW70, April 2005). The head is shown and spring dimensions $\sim 24 \mathrm{~m} \times 12 \mathrm{~m} \times 0.05 \mathrm{~m}$ deep. About $30 \%$ of all RFBE individuals are present in this spring. Photo: S. Brooks.
(Table 2). Where RFBE have been recorded in the same spring on separate occasions, estimated population numbers have apparently fluctuated to the extent of a doubling or halving of the population within a few months (Table 2). At the most recent survey in 2006 RFBE was present in five individual springs. Total wetland area of these five springs is $\sim 0.3$ ha.

RFBE adults generally occupy water depth between $10 \mathrm{~mm}$ and $40 \mathrm{~mm}$ (Fig. 4), although they can regularly occur in water less than $10 \mathrm{~mm}$ deep when summer evaporation restricts the availability of habitat (Fig. 4). Juvenile RFBE occupy shallower habitat than adult RFBE (Fig. 6), mostly within the range of $5 \mathrm{~mm}$ and $10 \mathrm{~mm}$ deep. These patterns are not mirrored by temperature differences, with both adult and juvenile RFBE occupying the full range of daytime temperatures (Fig. 5).

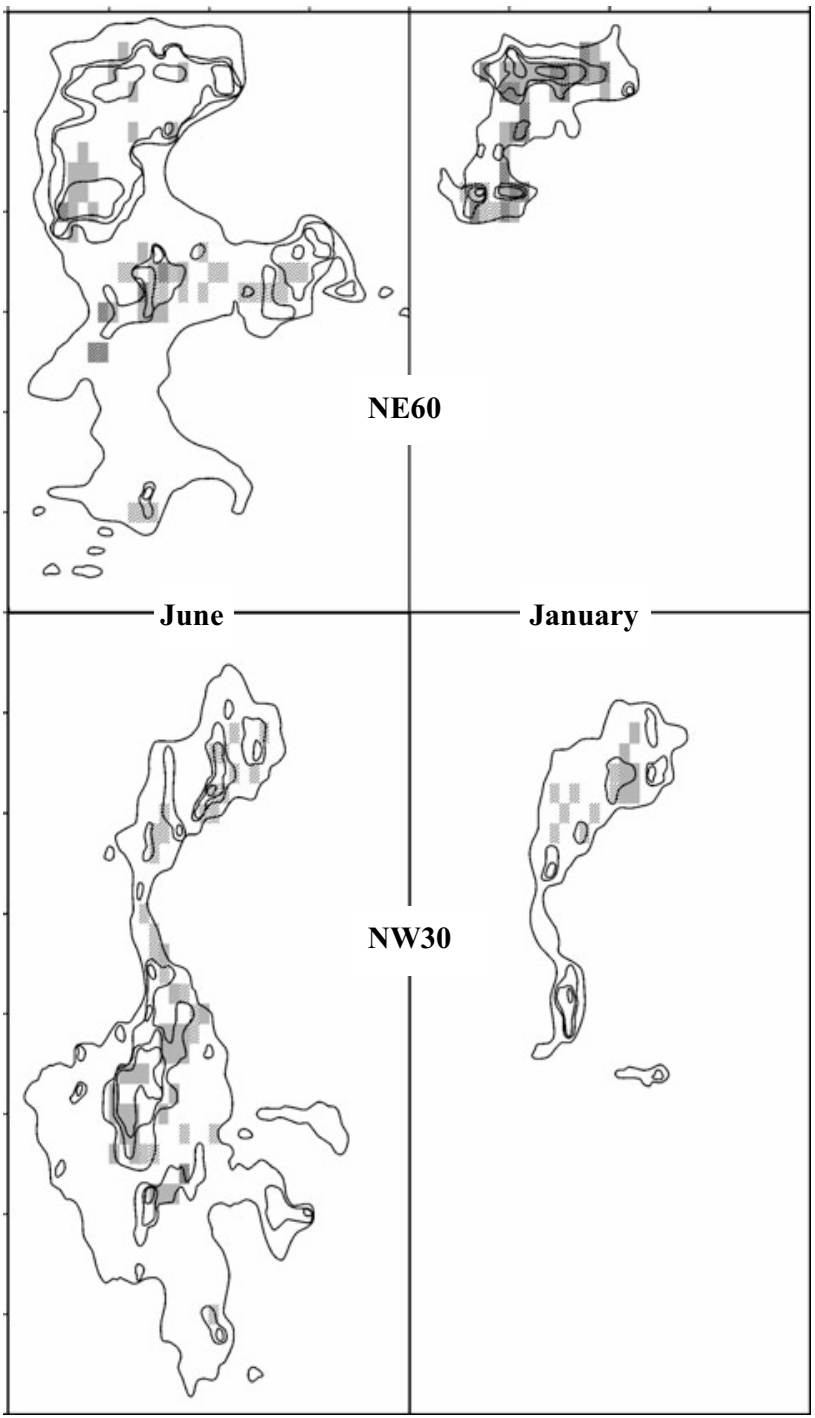

Fig. 4. Maps of two spring wetlands in winter (June) and summer (January) showing depth contours and fish distributions. Contours are 0,10 , 20 and $40 \mathrm{~mm}$. Ticks on the top and left margins are $10 \mathrm{~m}$ apart. For NE60, shaded cells represent the presence of Gambusia and striped cells the presence of RFBE. For NW30, shaded cells represent the presence of adult RFBE and striped cells the presence of juvenile RFBE. 
Table 1. Water chemistry data for some of the Edgbaston Springs

Data are combined from Fensham and Fairfax (2003) and Wager (1994). Units are in $\mathrm{mg} \mathrm{L}^{-1}$ unless otherwise specified

\begin{tabular}{|c|c|c|c|c|c|}
\hline & $N$ & Minimum & Median & Mean & Maximum \\
\hline Total dissolved solids & 12 & 463 & 711.5 & 833.25 & 2597 \\
\hline Total alkalinity & 13 & 210 & 335 & 402.31 & 1380 \\
\hline F & 27 & 0.5 & 0.78 & 1.27 & 5 \\
\hline $\mathrm{Cl}$ & 29 & 0.55 & 92 & 113.41 & 459 \\
\hline $\mathrm{Br}$ & 17 & 0.25 & 0.49 & 0.57 & 1.7 \\
\hline $\mathrm{NO}_{3}$ & 19 & 0 & 3.27 & 13.24 & 152 \\
\hline $\mathrm{PO}_{4}$ & 17 & 0.03 & 0.13 & 1.13 & 4.5 \\
\hline $\mathrm{SO}_{4}$ & 19 & 0 & 3.55 & 5.01 & 29.7 \\
\hline $\mathrm{Ca}^{4}$ & 30 & 2 & 3.35 & 4.28 & 13.7 \\
\hline $\mathrm{Mg}$ & 19 & 0 & 0.44 & 0.57 & 2.8 \\
\hline $\mathrm{Na}$ & 29 & 115 & 222 & 278.1 & 970 \\
\hline $\mathrm{K}$ & 30 & 0.2 & 2.73 & 6.6 & 68.6 \\
\hline $\mathrm{Si}$ & 17 & 9.2 & 29 & 32.18 & 77 \\
\hline $\mathrm{S}$ & 17 & 0.1 & 0.64 & 1.82 & 13.3 \\
\hline Total hardness & 13 & 5 & 10 & 9.62 & 25 \\
\hline $\mathrm{HCO}_{3}$ & 13 & 256 & 409 & 440.25 & 1385 \\
\hline Sodium adsorption ratio & 14 & 14.4 & 29.75 & 34.4 & 88.6 \\
\hline Residual alkalinity (meq L ${ }^{-1}$ ) & 13 & 4.1 & 6.2 & 7.85 & 27.3 \\
\hline Dissolved Fe & 12 & 0 & 0.4 & 0.58 & 1.5 \\
\hline $\mathrm{NH}_{4}$ & 14 & 0.05 & 0.08 & 0.91 & 6.5 \\
\hline Raw $\mathrm{CO}_{2}$ & 13 & 0.06 & 18 & 34.33 & 129 \\
\hline Conductivity $\left(\mu \mathrm{S} \mathrm{cm}^{-1}\right)$ & 14 & 490 & 845 & 985 & 3300 \\
\hline $\mathrm{pH}$ & 23 & 7.3 & 7.98 & 7.98 & 9.1 \\
\hline
\end{tabular}

Table 2. Occurrence of red-finned blue-eye (RFBE) and population estimates where available

Only those springs in which RFBE have ever been recorded are included. P, present; F, few; NV, not visited; N, surveyed but not found; A, Abundant; *, translocated population

\begin{tabular}{|c|c|c|c|c|c|c|c|c|c|c|}
\hline \multirow[t]{2}{*}{ Date } & \multicolumn{10}{|c|}{ Spring } \\
\hline & NE40 & NE50 & NE60 & NW30 & NW70 & NW90n & NW90s & SW50* & SW60* & SW70 \\
\hline Nov. 1990 & NV & $\mathrm{NV}$ & NV & $\mathrm{P}$ & $\mathrm{NV}$ & NV & $\mathrm{NV}$ & NV & NV & $\mathrm{N}$ \\
\hline Dec. 1990 & $\mathrm{~F}$ & $\mathrm{P}$ & A & $\mathrm{P}$ & $\mathrm{NV}$ & A & $\mathrm{A}$ & $\mathrm{N}$ & NV & $\mathrm{N}$ \\
\hline Apr. 1991 & F & $\mathrm{P}$ & F & $\mathrm{P}$ & $\mathrm{NV}$ & NV & NV & NV & NV & $\mathrm{NV}$ \\
\hline Jun. 1991 & $\mathrm{~F}$ & $\mathrm{P}$ & F & $P$ & NV & 800 & $\mathrm{~F}$ & NV & NV & NV \\
\hline Jul. 1991 & $\mathrm{~F}$ & $\mathrm{~N}$ & F & 400 & $\mathrm{NV}$ & $\mathrm{P}$ & $\mathrm{N}$ & $\mathrm{N}$ & NV & $\mathrm{N}$ \\
\hline Sep. 1991 & $\mathrm{~F}$ & $\mathrm{~N}$ & F & $\mathrm{P}$ & $\mathrm{F}$ & $\mathrm{P}$ & $\mathrm{N}$ & $\mathrm{N}$ & $\mathrm{NV}$ & $\mathrm{N}$ \\
\hline Jan. 1992 & NV & $\mathrm{NV}$ & NV & $\mathrm{P}$ & $\mathrm{N}$ & $P$ & $\mathrm{~N}$ & NV & NV & NV \\
\hline Dec. 1992 & $\mathrm{NV}$ & NV & $\mathrm{NV}$ & $\mathrm{P}$ & $\mathrm{N}$ & $\mathrm{P}$ & $\mathrm{N}$ & $\mathrm{N}$ & NV & NV \\
\hline Aug. 1993 & $>1000$ & $\mathrm{~N}$ & 350 & 350 & $\mathrm{~N}$ & $>900$ & $\mathrm{~N}$ & $\mathrm{~N}$ & $\mathrm{~N}$ & 200 \\
\hline Dec. 1993 & $>1200$ & $\mathrm{~N}$ & $>212$ & 275 & $\mathrm{~N}$ & $>1000$ & $\mathrm{~N}$ & $\mathrm{~N}$ & $8^{*}$ & 750 \\
\hline Jan. 1994 & $>1350$ & $\mathrm{~N}$ & 187 & 300 & $\mathrm{~N}$ & $>1000$ & $\mathrm{~N}$ & $\mathrm{~N}$ & $25^{*}$ & $>1450$ \\
\hline Apr. 1994 & 3000 & $\mathrm{~N}$ & 353 & 1100 & 1 & 1500 & $\mathrm{~N}$ & $\mathrm{~N}$ & $5^{*}$ & $>700$ \\
\hline Jun. 1994 & $>1500$ & $\mathrm{~N}$ & 150 & 400 & $\mathrm{~N}$ & 550 & $\mathrm{~N}$ & $\mathrm{~N}$ & $40^{*}$ & $<600$ \\
\hline Nov. 1994 & $\mathrm{P}$ & $\mathrm{N}$ & $\mathrm{P}$ & $\mathrm{P}$ & $\mathrm{N}$ & $\mathrm{P}$ & $\mathrm{N}$ & $\mathrm{N}$ & $\mathrm{P}^{*}$ & $\mathrm{P}$ \\
\hline Aug. 1995 & $\mathrm{P}$ & $\mathrm{N}$ & $\mathrm{P}$ & $\mathrm{P}$ & $\mathrm{N}$ & $\mathrm{P}$ & $\mathrm{N}$ & $\mathrm{N}$ & $\mathrm{P}^{*}$ & $\mathrm{P}$ \\
\hline Oct. 1995 & $\mathrm{P}$ & $\mathrm{N}$ & $\mathrm{P}$ & $\mathrm{P}$ & $\mathrm{P}$ & $\mathrm{P}$ & $\mathrm{N}$ & $\mathrm{N}$ & $\mathrm{P}^{*}$ & $\mathrm{P}$ \\
\hline Feb. 1996 & $\mathrm{P}$ & $\mathrm{N}$ & $\mathrm{P}$ & $\mathrm{P}$ & $\mathrm{N}$ & $\mathrm{P}$ & $\mathrm{N}$ & $\mathrm{N}$ & $\mathrm{P}^{*}$ & $\mathrm{P}$ \\
\hline Apr. 1996 & A & $\mathrm{N}$ & $<10$ & $\mathrm{P}$ & $\mathrm{N}$ & $\mathrm{P}$ & $\mathrm{N}$ & $\mathrm{N}$ & $\mathrm{P}^{*}$ & $\mathrm{P}$ \\
\hline Jul. 1996 & $P$ & $\mathrm{~N}$ & $<10$ & $P$ & $10^{*}$ & $P$ & $\mathrm{~N}$ & $31 *$ & $40^{*}$ & $P$ \\
\hline Oct. 1996 & $\mathrm{P}$ & $\mathrm{N}$ & $<10$ & $\mathrm{P}$ & $8^{*}$ & $\mathrm{P}$ & $\mathrm{N}$ & $\mathrm{P}^{*}$ & $\mathrm{P}^{*}$ & $\mathrm{P}$ \\
\hline May 1997 & $P$ & $\mathrm{~N}$ & $<50$ & $\mathrm{P}$ & $\mathrm{N}$ & $\mathrm{P}$ & $\mathrm{N}$ & $\mathrm{P}^{*}$ & $\mathrm{P}^{*}$ & F \\
\hline Oct. 1997 & $\mathrm{P}$ & $\mathrm{N}$ & 50 & 1000 & $\mathrm{~N}$ & $>1000$ & $\mathrm{~N}$ & $\mathrm{P}^{*}$ & $\mathrm{P}^{*}$ & $\mathrm{~N}$ \\
\hline Apr. 2005 & 2 & $\mathrm{~N}$ & 100 & 750 & 500 & 300 & $\mathrm{~N}$ & $\mathrm{~N}$ & $\mathrm{~N}$ & $\mathrm{~N}$ \\
\hline Sep. 2006 & $\mathrm{~N}$ & $\mathrm{~N}$ & 400 & 1000 & 400 & 800 & $<100$ & $\mathrm{~N}$ & $\mathrm{~N}$ & $\mathrm{~N}$ \\
\hline
\end{tabular}


(a)

(b)

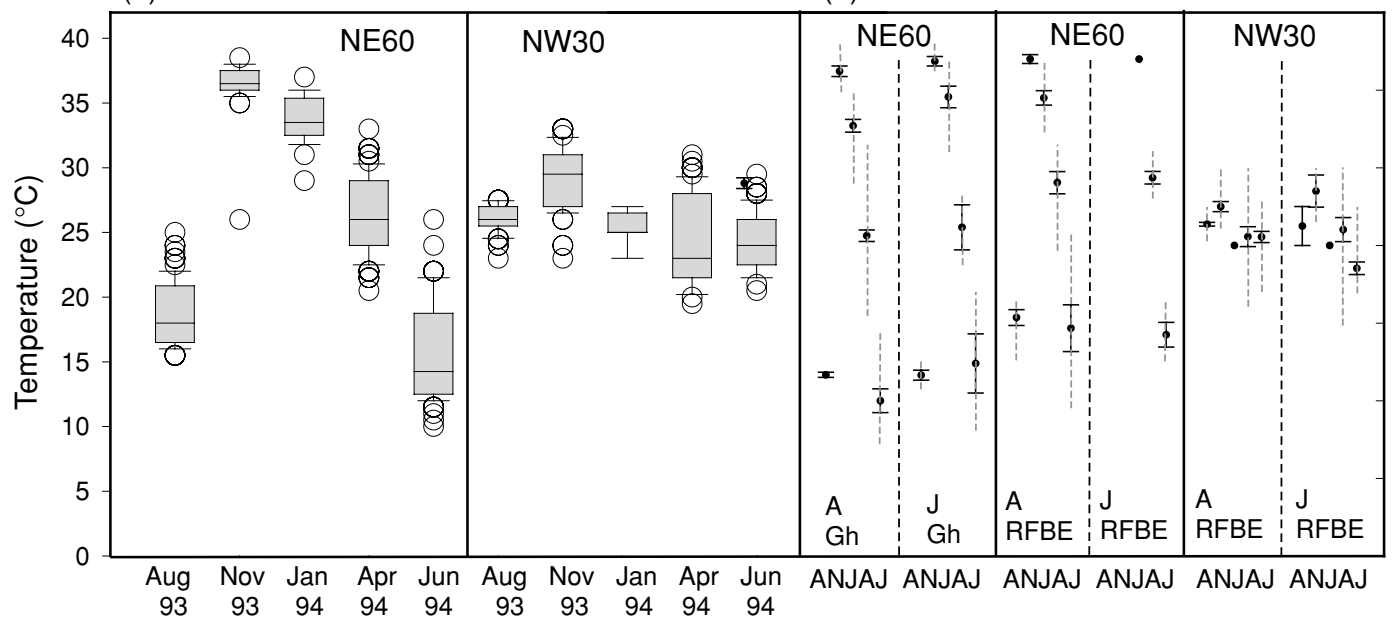

Fig. 5. (a) Temperature characteristics for springs NE60 and NW30 five times throughout one year. Boxes represent the 25th and 75th percentile, error bars represent the 10th and 90th percentile and median is the horizontal line within a box. Circles represent outliers. (b) Presence of adult and juvenile RFBE and Gambusia for the same springs at the same time according to temperature. Mean, standard error bars and the range are presented. NW30 does not contain Gambusia.

RFBE appear to have died out from five springs (NE40, NE50, NW70, NW90s and SW70: Table 2). Three natural colonisations also occurred in spring NW70. Two of these populations survived for less than four months and one continues to persist after at least 17 months. NW70 is $\sim 100 \mathrm{~m}$ downslope of NW30 on the same claypan and at least one colonisation occurred after a rainfall event. This spring is also the smallest containing RFBE ( $0.01 \mathrm{ha})$ and may therefore be more susceptible to desiccation and other threats may be exacerbated. NW90s was almost certainly colonised from NW90n as the outflow of these springs are occasionally connected.

\section{Translocation attempts}

There have been three attempts to translocate RFBE. Eight individuals taken from SW70 to SW60 in December 1993 bred but died out between 1997 and 2005 (Table 2). There was little available free water at this site in 2005. Thirty-one individuals taken from the same source and translocated to SW50 lasted between 14 months and nine years. Prior to translocation this spring had dried back sufficiently to eliminate a population of Gambusia (Wager 1994) and similar changes in flow between 1997 and 2005 may account for this translocation failure. The translocation of ten individuals from NW30 to NW70 was also unsuc-

(a)

(b)

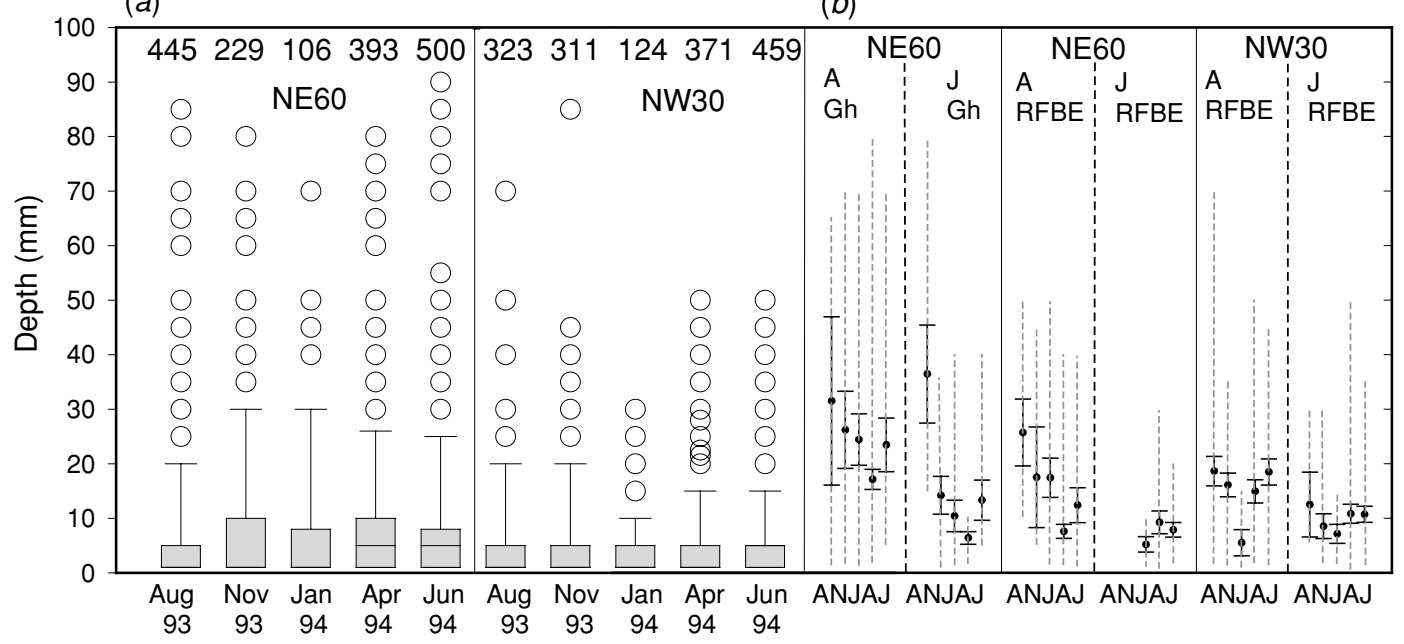

Fig. 6. (a) Depth characteristics of springs NE60 and NW30 five times throughout one year. Numbers at the top represent the number of wetland area cells sampled. Multiply by 0.0002 for total wetland area in hectares. Boxes represent the 25 th and 75 th percentile; error bars represent the 10th and 90th percentile. Circles represent outliers. (b) Presence of adult and juvenile RFBE and Gambusia for the same springs at the same time according to depth. Mean, standard error bars and the range are presented. NW30 does not contain Gambusia. 
Table 3. Occurrence of Gambusia and population estimates where available

Only those springs in which Gambusia have ever been recorded are included. P, present; F, few; NV, not visited; N, surveyed but not found, A, Abundant

\begin{tabular}{|c|c|c|c|c|c|c|c|c|c|c|c|c|c|c|c|c|c|c|}
\hline \multirow[t]{2}{*}{ Date } & \multicolumn{18}{|c|}{ Spring } \\
\hline & NE20 & NE30 & NE40 & NE50 & NE60 & NW10 & NW90 & sNW100 & SE10 & SE20 & SE30 & SE40 & SE50 & SE60 & SW10 & SW40 & SW50 & SW70 \\
\hline Nov. 1990 & NV & NV & NV & NV & NV & $\mathrm{P}$ & NV & NV & NV & NV & NV & NV & NV & NV & NV & NV & NV & $\mathrm{P}$ \\
\hline Dec. 1990 & NV & NV & $\mathrm{F}$ & $\mathrm{P}$ & $\mathrm{P}$ & NV & $\mathrm{P}$ & $\mathrm{P}$ & NV & NV & NV & NV & NV & NV & NV & NV & NV & $\mathrm{P}$ \\
\hline Apr. 1991 & NV & $\mathrm{N}$ & $\mathrm{F}$ & A & A & A & NV & $\mathrm{P}$ & NV & NV & NV & NV & NV & NV & NV & NV & NV & NV \\
\hline Jun. 1991 & NV & $\mathrm{N}$ & $\mathrm{P}$ & A & $\mathrm{P}$ & NV & $\mathrm{P}$ & $\mathrm{P}$ & NV & NV & NV & NV & NV & NV & NV & NV & NV & NV \\
\hline Jul. 1991 & NV & $\mathrm{N}$ & $\mathrm{N}$ & A & A & $\mathrm{P}$ & 35 & $\mathrm{P}$ & NV & NV & $\mathrm{P}$ & NV & NV & NV & $\mathrm{P}$ & $\mathrm{P}$ & $\mathrm{P}$ & $\mathrm{P}$ \\
\hline Sep. 1991 & NV & $\mathrm{N}$ & $\mathrm{N}$ & A & A & $\mathrm{P}$ & $\mathrm{N}$ & $\mathrm{P}$ & NV & NV & $\mathrm{P}$ & $\mathrm{N}$ & NV & NV & $\mathrm{P}$ & $\mathrm{N}$ & 1 & $\mathrm{P}$ \\
\hline Jan. 1992 & $\mathrm{NV}$ & $\mathrm{NV}$ & NV & NV & NV & $\mathrm{NV}$ & $\mathrm{N}$ & NV & NV & NV & NV & NV & NV & NV & $\mathrm{NV}$ & NV & $\mathrm{NV}$ & NV \\
\hline Dec. 1992 & $\mathrm{~N}$ & NV & NV & NV & NV & NV & $\mathrm{N}$ & $\mathrm{P}$ & NV & NV & NV & $\mathrm{N}$ & NV & $\mathrm{N}$ & NV & NV & NV & NV \\
\hline Aug. 1993 & $\mathrm{~N}$ & $\mathrm{~N}$ & 5 & A & $\mathrm{P}$ & $\mathrm{P}$ & $\mathrm{N}$ & $\mathrm{P}$ & A & $\mathrm{P}$ & $\mathrm{P}$ & $\mathrm{N}$ & NV & $\mathrm{N}$ & $\mathrm{P}$ & $\mathrm{N}$ & $\mathrm{N}$ & $\mathrm{P}$ \\
\hline Dec. 1993 & $\mathrm{~N}$ & $\mathrm{~N}$ & 200 & 6 & $>600$ & NV & $\mathrm{N}$ & $\mathrm{P}$ & $\mathrm{P}$ & NV & $\mathrm{P}$ & $\mathrm{N}$ & NV & $\mathrm{N}$ & NV & $\mathrm{N}$ & $\mathrm{N}$ & $\mathrm{P}$ \\
\hline Jan. 1994 & $\mathrm{~N}$ & $\mathrm{~N}$ & 500 & 200 & 750 & $\mathrm{P}$ & $\mathrm{N}$ & $\mathrm{P}$ & A & NV & $\mathrm{P}$ & $\mathrm{N}$ & NV & $\mathrm{N}$ & $\mathrm{N}$ & $\mathrm{N}$ & $\mathrm{N}$ & $\mathrm{P}$ \\
\hline Apr. 1994 & $\mathrm{~N}$ & $\mathrm{~N}$ & 1000 & $>300$ & 1740 & $\mathrm{P}$ & $\mathrm{N}$ & $\mathrm{P}$ & A & $\mathrm{P}$ & $\mathrm{P}$ & $\mathrm{N}$ & $\mathrm{P}$ & $\mathrm{N}$ & $\mathrm{P}$ & $\mathrm{N}$ & $\mathrm{N}$ & $\mathrm{P}$ \\
\hline Jun. 1994 & $\mathrm{~N}$ & $\mathrm{~N}$ & 1000 & 300 & $>120$ & A & $\mathrm{N}$ & $\mathrm{P}$ & A & NV & $\mathrm{P}$ & $\mathrm{N}$ & NV & $\mathrm{N}$ & $P$ & $\mathrm{~N}$ & $\mathrm{~N}$ & $\mathrm{P}$ \\
\hline Nov. 1994 & $\mathrm{~N}$ & $\mathrm{~N}$ & $\mathrm{P}$ & $\mathrm{P}$ & $\mathrm{P}$ & $\mathrm{P}$ & $\mathrm{N}$ & $\mathrm{P}$ & $\mathrm{P}$ & NV & NV & $\mathrm{N}$ & NV & $\mathrm{N}$ & $\mathrm{P}$ & $\mathrm{N}$ & $\mathrm{N}$ & $\mathrm{P}$ \\
\hline Aug. 1995 & $\mathrm{~N}$ & $\mathrm{~N}$ & $\mathrm{P}$ & $\mathrm{P}$ & $\mathrm{P}$ & $\mathrm{P}$ & $\mathrm{N}$ & $\mathrm{P}$ & $\mathrm{P}$ & $\mathrm{P}$ & $\mathrm{P}$ & $\mathrm{N}$ & $\mathrm{N}$ & $\mathrm{N}$ & $\mathrm{P}$ & $\mathrm{N}$ & $\mathrm{N}$ & $\mathrm{P}$ \\
\hline Oct. 1995 & $\mathrm{~N}$ & $\mathrm{~N}$ & $\mathrm{P}$ & $\mathrm{P}$ & $P$ & $\mathrm{P}$ & $\mathrm{N}$ & $\mathrm{P}$ & $\mathrm{P}$ & $\mathrm{P}$ & $\mathrm{P}$ & $\mathrm{N}$ & $\mathrm{N}$ & $\mathrm{N}$ & $P$ & $\mathrm{~N}$ & $\mathrm{~N}$ & $\mathrm{P}$ \\
\hline Feb. 1996 & $\mathrm{~N}$ & $\mathrm{~N}$ & $\mathrm{P}$ & $\mathrm{P}$ & $\mathrm{P}$ & $\mathrm{P}$ & $\mathrm{N}$ & $\mathrm{P}$ & $\mathrm{P}$ & NV & $\mathrm{NV}$ & $\mathrm{N}$ & $\mathrm{NV}$ & $\mathrm{N}$ & $\mathrm{P}$ & $\mathrm{N}$ & $\mathrm{N}$ & $\mathrm{P}$ \\
\hline Apr. 1996 & $\mathrm{~N}$ & $\mathrm{~N}$ & $\mathrm{P}$ & $\mathrm{P}$ & $\mathrm{P}$ & $\mathrm{P}$ & $\mathrm{N}$ & $\mathrm{P}$ & $\mathrm{P}$ & $\mathrm{P}$ & $\mathrm{P}$ & $\mathrm{N}$ & $\mathrm{P}$ & $\mathrm{N}$ & $\mathrm{P}$ & $\mathrm{N}$ & $\mathrm{N}$ & $\mathrm{P}$ \\
\hline Jul. 1996 & $\mathrm{~N}$ & $\mathrm{~N}$ & $P$ & $\mathrm{P}$ & $P$ & $\mathrm{P}$ & $\mathrm{N}$ & $\mathrm{P}$ & $\mathrm{P}$ & $\mathrm{P}$ & $\mathrm{P}$ & $\mathrm{N}$ & $\mathrm{P}$ & $\mathrm{N}$ & $P$ & $\mathrm{~N}$ & $\mathrm{~N}$ & $\mathrm{P}$ \\
\hline Nov. 1996 & $\mathrm{~N}$ & $\mathrm{~N}$ & $\mathrm{P}$ & P & $\mathrm{P}$ & $\mathrm{P}$ & $\mathrm{N}$ & $\mathrm{P}$ & $\mathrm{P}$ & $\mathrm{P}$ & $\mathrm{P}$ & $\mathrm{N}$ & $\mathrm{P}$ & $\mathrm{N}$ & $\mathrm{P}$ & $\mathrm{P}$ & $\mathrm{N}$ & $\mathrm{P}$ \\
\hline May 1997 & $\mathrm{~N}$ & $\mathrm{~N}$ & $\mathrm{P}$ & $\mathrm{P}$ & $\mathrm{P}$ & $\mathrm{P}$ & $\mathrm{N}$ & $\mathrm{P}$ & $\mathrm{P}$ & $\mathrm{P}$ & $\mathrm{P}$ & $\mathrm{N}$ & $\mathrm{P}$ & $\mathrm{N}$ & $\mathrm{P}$ & $\mathrm{P}$ & $\mathrm{N}$ & $\mathrm{P}$ \\
\hline Oct. 1997 & $\mathrm{~N}$ & $\mathrm{~N}$ & $P$ & $\mathrm{P}$ & $P$ & $\mathrm{P}$ & $\mathrm{N}$ & $\mathrm{P}$ & $\mathrm{P}$ & $\mathrm{P}$ & $\mathrm{P}$ & $\mathrm{N}$ & $\mathrm{P}$ & $\mathrm{N}$ & $\mathrm{P}$ & $\mathrm{N}$ & $\mathrm{N}$ & $\mathrm{P}$ \\
\hline Apr. 2005 & 350 & $\mathrm{~N}$ & 3000 & 650 & 3000 & A & $\mathrm{N}$ & 500 & 2000 & $\mathrm{~N}$ & 1000 & 100 & 400 & 500 & $\mathrm{~N}$ & Y & 2000 & $>3000$ \\
\hline Sep. 2006 & $>100$ & $>100$ & $>1000$ & $>1000$ & 3000 & $>1000$ & $\mathrm{~N}$ & 500 & $\mathrm{P}$ & $\mathrm{N}$ & $\mathrm{P}$ & NV & $\mathrm{P}$ & $\mathrm{P}$ & $\mathrm{N}$ & NV & $\mathrm{P}$ & $>2000$ \\
\hline
\end{tabular}

cessful. Monitoring data suggest that RFBE have appeared and disappeared from this spring twice previously (Table 2).

\section{Competition with gambusia (Gambusia holbrooki)}

Native to North America, Gambusia bear live young, are omnivorous and generalist feeders, defend resources aggressively, have a high reproductive output, proven dispersal and colonising ability, flexible genotype (Lloyd 1984), and thrive in a wide range of extremely modified habitats (e.g. Arthington et al. 1983). Adult females usually reach $6 \mathrm{~cm}$ total length (twice adult RFBE length) and prefer shallow, warm water $\left(\sim 25^{\circ} \mathrm{C}\right)$ although they can survive temperatures from near freezing to $44^{\circ} \mathrm{C}$ (Lloyd 1984).
Gambusia were collected from Edgbaston when the first biologist visited in 1984. According to a local resident, Gambusia were present in a bore drain when he arrived in the early 1970s (F. Manwaring, pers. comm.). In 2005, Gambusia were present and abundant in 14 Edgbaston Springs, including five of the eight in which the RFBE is known to have naturally occurred (Table 3).

Gambusia were present in NE40, NE50, NW90s, SW70 and possibly SW50 when RFBE populations were lost from these springs (Tables 2, 3), are present in springs with the most recent lowest observed RFBE numbers, and absent from springs with the three largest RFBE populations. Two of these occur at relatively high elevations and may have avoided

Table 4. Results of ANOVAs testing the significance of depth occupancy of juvenile red-finned blueeye (RFBE) between springs, adult RFBE between springs, and adult RFBE and adult Gambusia where they co-occur

For juvenile RFBE, only January, April and August are included because of the absence of RFBE juveniles in other months

\begin{tabular}{llcccc}
\hline Species-age & Source of variation & s.s. & d.f. & $F$ & $P$ \\
\hline Juvenile RFBE & Spring & 130.92 & 1 & 1.86 & 0.175 \\
& Season & 145.10 & 2 & 1.03 & 0.360 \\
Adult RFBE & Spring $\times$ season & 7.87 & 2 & 0.06 & 0.946 \\
& Spring & 371.43 & 1 & 2.21 & 0.138 \\
& Season & 1463.92 & 4 & 2.18 & 0.072 \\
Adult RFBE and Gambusia & Spring $\times$ season & 1892.33 & 4 & 2.82 & 0.026 \\
where they co-occur & Species & 2000.10 & 1 & 6.32 & 0.013 \\
& Season & 4591.82 & 4 & 3.63 & 0.007 \\
& Species $\times$ season & 92.41 & 4 & 0.07 & 0.990 \\
\hline
\end{tabular}


colonisation by Gambusia during floods that connected springs at lower elevations.

In spring, NE60, which contains both RFBE and Gambusia, $21 \%$ of cells containing RFBE in June also contained Gambusia, whereas that figure was $77 \%$ in January. These seasonal differences in the overlap of horizontal space between the species suggest that RFBE prefer to occupy separate parts of the spring, but are forced to cohabit when summer evaporation drastically reduces spring size (Fig. 4). In January Gambusia density in cells without RFBE averaged 13.2 individuals $\mathrm{m}^{-2}$, in cells containing both species Gambusia density averaged 10.6 individuals $\mathrm{m}^{-2}$ and RFBE 2.1 individuals $\mathrm{m}^{-2}$, while RFBE density in cells without Gambusia averaged 5.5 individuals $\mathrm{m}^{-2}$.

Depth occupied by adult Gambusia and adult RFBE was still significantly different regardless of the increased overlap between species when wetland area decreased (Table 4). The lack of significant difference between depth of water occupied by both adult and juvenile RFBE between springs with and without Gambusia (Table 4) suggests that competition may be partly avoided, but it may also be accounted for by the generally shallower spring without Gambusia (NW30, Fig. 6).

There is no evidence from the monitoring that separation of Gambusia and RFBE within a spring relates to water temperature (Fig. 5). However, competition may intensify when extreme water temperatures in winter render the shallower parts of the spring unfavourable. During these times the vent areas may become prime habitat due to their warmer and more stable temperatures (see Minckley 1999 for an analogous example). Separate schools of each species have been observed in vent areas where space permits and both species can display aggressive behaviour to the other. Fin nipping of RFBE has been documented by Unmack and Brumley (1991), and Wager (1994) records that in spring NE60 in January $96 \%$ of observed RFBE had damaged caudal fins. Observations of Gambusia fin-nipping RFBE appear to be confined to summer when space is most limited (Fig. 4).

The impact of predation by Gambusia on RFBE is not known although the absence of fry and juvenile RFBE at certain times has been attributed to Gambusia (Wager 1994). Larvae from other pseudomugilid species have been recorded in the diet of wild Gambusia (Ivantsoff and Aarn 1999). Gambusia may also act as a vector for disease and have been observed with worms and fungal infections within Edgbaston Springs. Fungal infections and death of Australian native fish have been observed as a result of fin nipping by Gambusia (McKay 1984).

Gambusia population sizes at Edgbaston appear to periodically decline, possibly due to low water temperatures or deteriorating water quality resulting from stock or pig damage (e.g. NE50, see below). They died out from SW50 when suitable habitat temporarily dried out and have since recolonised (Table 3). They also disappeared from two fully excavated springs (SW10 and SW40) and from NW90s a few weeks after RFBE was last seen there (June 1991).

Despite circumstantial evidence of negative interactions between the species, evidence that Gambusia is entirely responsible for RFBE decline is ambiguous because both have coexisted in NE60 for at least 15 years (Tables 2 and 3). However, the limited number and size of springs, limited habitat within springs, apparently fluctuating populations of RFBE, observa- tions of direct competitive behaviour, higher rate of RFBE loss in springs containing Gambusia, colonising ability at Edgbaston, the potential for Gambusia as an agent of disease (Dove 1998), and evidence from elsewhere indicate that Gambusia pose a real threat.

\section{Animal disturbance and ponded pasture}

Apart from permanent drinking water, the springs support herbage palatable to stock. During August 1993 in spring NW30 $100 \%$ of the total population of a wetland grass Pennisetum alopecurioides showed evidence of being grazed, and $74 \%$ the following November (late dry season). At the same monitoring times 11 of 15 depth point intercepts of water deeper than $30 \mathrm{~mm}$ were associated with hoof prints. Approximately $3 \%$ and $0 \%$ of the RFBE population occupied the area around these hoof-prints in August and November respectively, but occupied similar water depths not associated with disturbance. Domestic stock and pigs have both been observed to trample and uproot vegetation, increase turbidity and affect depth and flow within springs. Stock and pig faeces and rotting carcasses have been present in springs containing RFBE and can increase ammonium ion levels. In the confined, warm, alkaline spring environments these can combine with hydroxyl ions to form ammonia levels toxic to fish (see Erickson 1985).

Use of springs by cattle in the USA, and consequent increases in ammonia, nitrites, pathogenic bacteria and decreases in dissolved oxygen resulted in increased mortality and morbidity of endemic fish (Taylor et al. 1989). Fish populations recovered after stock removal, although negative effects can appear months after stock use, depending on site and seasonal conditions, notably rainfall and water temperature (Hall and Amy 1990).

Dramatic declines in the population of Gambusia have been attributed to extreme fouling by stock in NE50 during 1993 (Wager 1994), and due to a dead beast in SW70 during September 1991. The following month ammonia levels in excess of 4 ppm were recorded in this spring (Wager 1998).

In 1997 two springs were fenced from cattle, sheep and goats and provided partial protection from pigs. One of these springs (NE60) is the only location where Gambusia and RFBE have coexisted for a long period. The improved habitat due to animal exclusion may have assisted RFBE survival in this instance.

Some level of grazing may be beneficial to RFBE habitat if it results in greater volume of free water through reduced evapotranspiration. A population of the endangered Sonoran topminnow was lost after a species of Typha invaded a spring following fencing from stock (Marsh and Minckley 1990). Typha is present in low numbers at Edgbaston, along with Phragmites, which has significantly reduced wetland area of GAB springs elsewhere following removal of stock (Fatchen and Fatchen 1993). The importance of vegetation structure as shelter and spawning grounds for RFBE populations is yet to be understood. Grazing by native herbivores probably has a relatively benign influence on RFBE habitat.

An exotic ponded pasture species, para-grass (Brachiaria mutica), has been planted in one of the excavated springs. At present it is a relatively small population and has not spread beyond that spring. However, in other GAB springs para-grass has obliterated the habitat provided by native plant species (Fensham and Fairfax 2003). 


\section{Excavation}

A large percentage of Queensland's GAB spring wetlands have been destroyed by excavation (Fensham and Fairfax 2003). The aim of excavation is to provide easier access to cleaner water for domestic stock and typically involves dredging the spring or area around the vent. Three springs at Edgbaston have been totally excavated and it is not known whether these contained RFBE. For this reason there is no direct evidence of negative impacts of excavation on RFBE but it is highly unlikely that RFBE would survive major excavation. Turbidity appears higher in fully excavated springs and even Gambusia populations may be less persistent in these springs (e.g. SW10 and SW40). The diversity of endemic invertebrates appears lower in excavated springs on Edgbaston (W. Ponder, pers. comm.), as does floristic diversity. Partial excavation has occurred in two springs that contained RFBE at the time (NE40 and SW70). However, pig damage, stock damage and Gambusia probably had a greater role in RFBE elimination from these springs.

\section{Harvesting from in situ populations}

Interviews with the keepers of captive RFBE and specimen records indicate that perhaps 1000 RFBE have been removed, mostly within the first few years of their discovery. For the springs without Gambusia at the time of harvesting there does not seem to have been any lasting impact on population numbers. RFBE has disappeared from springs that were subject to harvesting (NE40 and NE50) but these springs also contained Gambusia. Fish harvesting is probably not a major current threat to this species, although its potential is recognised for RFBE (Wager and Unmack 2004) and similar species (e.g. Ng and Tan 1997).

All known Australian and European captive RFBE have not survived. Only a few captive populations persisted beyond two generations. One population persisted for about seven generations, although unlike other captive attempts this included additional genetic input (Tappin 1999). Published accounts of captive breeding not cited elsewhere in this paper are Grunwald (1995), Tappin (1995b), Pearson (1999) and Walker (2005).

\section{Recovery actions, research and threat mitigation}

The first recovery plan for RFBE (Wager 1995) was generally not implemented, although RFBE has been recognised as endangered at state (Queensland; Nature Conservation (Wildlife) Regulation 2006), national (Environment Protection and Biodiversity Conservation Act 1999) and international levels (IUCN 2006). Bore capping and piping is progressing steadily and should result in increased aquifer pressure, a reduction in regional Gambusia populations because of reduced bore drain habitat, and partially restored flows to spring wetlands. An 'expression of interest' has been made by landholders to participate in a capping and piping scheme for nine of the remaining 52 uncapped bores within $70 \mathrm{~km}$ of Edgbaston. However, not all land managers prefer the option of capping bores and piping water to designated water points over open drains. Some bore drains transgress property boundaries and community resolution is required. The Queensland State Government GAB Draft Water Resource Plan has scope for prescribing maximum cumulative impact of aquifer draw-down on GAB springs, and for restricting water allocations in the vicinity of high-conservation-value springs (Water Management and Use Group 2005). The bores that have the greatest influence on the springs need to be clearly identified and managed accordingly. A remote-sensing project initiated in 2006 aims to monitor wetland area at Edgbaston and other GAB springs in relation to aquifer management.

Basic aspects of RFBE biology, including its life history, diet, reproductive biology and population characteristics in relation to seasonal and habitat conditions may inform management for the recovery of the RFBE population.

More information is required to assess the magnitude of the threat posed by Gambusia. There is a clear need for studies identifying environmental tolerances and niche overlap of Gambusia and RFBE. Carefully designed in situ monitoring would reveal the extent to which the life stages of RFBE are able to avoid Gambusia by virtue of their habitat tolerances in relation to water depth, level of occupancy, food sources, use of vegetative cover and reproductive characteristics. The occurrence of RFBE and habitat with and without Gambusia provides an opportunity to further the preliminary results presented here to define behavioural differences and competitive interactions. The confounding and negative effects of feral animals need to be eliminated.

Accurate elevation data of the Edgbaston Springs landscape would enhance predictions of spring connectivity in relation to rainfall events and reveal the sensitivity of each spring to colonisation by Gambusia. Methods of Gambusia removal should also be investigated but negative impact on other species has to be avoided. Unsustained attempts to physically remove Gambusia from several springs using various netting strategies (Wager 1994) have been predictably unsuccessful and population numbers of Gambusia recovered. Trapping may be most effective immediately before spring size declines in summer when negative interactions between RFBE and Gambusia increase. Gene technology aimed at affecting the reproductive capabilities of G. holbrooki has been trialed (Thresher and Bax 2003), and offers a promising solution, but this option will not be available for several years.

Densities of Typha and Phragmites should be monitored and, if necessary, regulated with domestic stock. Otherwise domestic stock should be excluded from key springs at least and native herbivores permitted. Feral populations of pigs and goats will be most effectively managed by a sustained culling program.

Wager (1995) identified five springs within the complex potentially suitable for additional translocations. RFBE have since naturally colonised one (NW70) and Gambusia the other four. While previous translocation attempts have failed, further efforts may be necessary and must consider long-term habitat suitability and effective Gambusia control. Nevertheless, 157 of 175 translocations of the Gila Topminnow into spring-fed habitat were failures (Minckley 1999). Translocation should have a lower priority than maintaining natural populations and habitat.

The failure of attempts to maintain captive breeding populations suggests that an intensive and dedicated effort would be required with due consideration given to water quality, population structure, microhabitat and diet. 


\section{Conclusion}

The RFBE has a very restricted habitat and clearly identified threatening processes and is certainly prone to extinction. The aquifer needs to be managed such that appropriate flows to the springs are maintained. Eliminating Gambusia where they already occur seems almost intractable, and preventing further Gambusia colonisation is a major priority. Excavation, domestic stock grazing, exotic grasses and rampant feral animal populations are avoidable negative influences on RFBE habitat. It is critically important that Edgbaston Springs are managed for their outstanding biological values. Given the uncertainties exposed by this paper, management will have to be adaptive and informed by responsible research.

\section{Acknowledgements}

The current landholders at Edgbaston, Alan and Fay Wills, have been inundated by biologists wanting to study the extraordinary springs on their property. Their patience and ongoing hospitality has been gratefully received by the authors and others over many years. Thanks go to Adrian Tappin, Chris Clague, Mike Hammer and anonymous referees for reviewing a draft manuscript. Will Smith generously prepared the spring maps. N. Armstrong, H. Bleher, R. Bowman, G. Briggs, J. Cousins, A. Dawson, J. Graf, N. Grunwald, K. Hand, B. Hansen, H. Heironimus, R. Leggett, G. Lenehan, G. Maebe, B. Pierce, G. Rich, R. Robinson, G. Schmida, T. Sim, A. Tappin and G. Walker are thanked for sharing their knowledge, experiences and support. The Department of Natural Resources, Mines and Water kindly supplied bore information.

\section{References}

Arthington, A. H. (1991). Ecological and genetic impacts of introduced and translocated freshwater fishes in Australia. Canadian Journal of Fisheries and Aquatic Sciences 48, 33-43. Suppl.1

Arthington, A. H., and Marshall, C. J. (1999). Diet of the exotic mosquitofish, Gambusia holbrooki, in an Australian lake and potential for competition with indigenous fish species. Asian Fisheries Science 12, 1-16.

Arthington, A. H., Milton, D. A., and Mackay, R. J. (1983). Effects of urban development and habitat alterations on the distribution and abundance of native and exotic freshwater fish in the Brisbane region, Queensland. Australian Journal of Ecology 8, 87-101. doi:10.1111/j.14429993.1983.tb01597.x

Clesceri, L. S., Greenberg, A. E., and Eaton, A. D. (Eds) (1998). 'Standard Methods for the Examination of Water and Wastewater.' (American Public Health Association: Washington, DC.)

Crivelli, A. J. (1995). Are fish introductions a threat to endemic freshwater fishes in the northern Mediterranean region? Biological Conservation 72, 311-319. doi:10.1016/0006-3207(94)00092-5

Dove, A. D. M. (1998). A silent tragedy: parasites and the exotic fishes of Australia. Proceedings of the Royal Society of Queensland 107, $109-113$.

Elvira, B. (1995). Conservation status of endemic freshwater fish in Spain. Biological Conservation 72, 129-136. doi:10.1016/0006-3207(94) 00076-3

Erickson, R. J. (1985). Evaluation of mathematical models for the effects of $\mathrm{pH}$ and temperature on ammonia toxicity to aquatic organisms. Water Research 19, 1047-1058. doi:10.1016/0043-1354(85)90375-6

Fairfax, R. J., and Fensham, R. J. (2002). In the footsteps of J. Alfred Griffiths: a cataclysmic history of Great Artesian Basin springs in Queensland. Australian Geographical Studies 40, 210-230. doi:10.1111/1467-8470.00175

Fairfax, R. J., and Fensham, R. J. (2003). Great Artesian Basin springs in southern Queensland 1911-2000. Memoirs of the Queensland Museum 49, 285-293.
Fatchen, T. J., and Fatchen, D. H. (1993). Dynamics of vegetation on mound springs in the Hermit Hill region, northern South Australia. Report prepared for WMC (Olympic Dam Operations) Pty Ltd, Roxby Downs, SA.

Fensham, R. J., and Fairfax, R. J. (2003). Spring wetlands of the Great Artesian Basin, Queensland, Australia. Wetland Ecology and Management 11, 343-362. doi:10.1023/B:WETL.0000005532. 95598.e4

Great Artesian Basin Consultative Council (GABCC) (2000). 'Great Artesian Basin Strategic Management Plan. September 2000.' (Great Artesian Basin Consultative Council: Canberra.)

Grunwald, N. (1995). Appendix to Adrian Tappins report. Regenbogenfisch 2, 28-29.

Habermehl, M. A. (2001). Hydrogeology and environmental geology of the Great Artesian Basin, Australia. In 'Gondwana to Greenhouse Australian Environmental Geoscience’. (Ed. V. A. Gostin.) pp. 127-143, 344-346. Geological Society of Australia Special Publication 21.

Hall, D. A., and Amy, P. S. (1990). Microbiology and water chemistry of two natural springs impacted by grazing in south central Nevada. Great Basin Naturalist 50, 289-294.

Howe, E., Howe, C., Lim, R., and Burchett, M. (1997). Impact of the introduced poeciliid Gambusia holbrooki (Girard, 1859) on the growth and reproduction of Pseudomugil signifer (Kner, 1865) in Australia. Marine and Freshwater Research 48, 425-434. doi:10.1071/MF96114

IUCN (2006). '2006 IUCN Red List of Threatened Species.' www.iucnredlist.org [Verified on 9 May 2006].

Ivantsoff, W., Aarn, (1999). Detection of predation of Australian native fishes by Gambusia holbrooki. Marine and Freshwater Research 50, $467-468$

Ivantsoff, W., Unmack, P., Saeed, B., and Crowley, L. E. L. M. (1991). A redfinned blue-eye, a new species and genus of the family Pseudomugilidae from central western Queensland. Fishes of Sahul 6, 277-282.

Kinhill Engineers Pty Ltd (1997). 'Olympic Dam Expansion Project Environmental Impact Statement.' (WMC (Olympic Dam Corporation) Pty Ltd: Adelaide.)

Lloyd, L. (1984). Exotic fish: useful additions or 'animal weeds'? Fishes of Sahul 1, 31-42.

Lloyd, L. N., Arthington, A. H., and Milton, D. A. (1986). The mosquitofish - a valuable mosquito-control agent or a pest? In 'The Ecology of Exotic Animals and Plants in Australia'. (Ed. R. L. Kitching.) pp. 6-25. (Jacaranda Press: Melbourne.)

Marsh, P. C., and Minckley, W. L. (1990). Management of endangered Sonoran topminnow at Bylass Springs, Arizona: description, critique, and recommendations. Great Basin Naturalist 50, 265-272.

McLaren, N., Wiltshire, D., and Lesslie, R. (1986). 'Biological Assessment of South Australian Mound Springs.' (South Australian Department of Environment and Planning: Adelaide.)

McKay, R. J. (1984). Introductions of exotic fish in Australia. In 'Distribution, Biology and Management of Exotic Fishes'. (Eds W. R. Courtenay and R. Stauffer.) pp. 177-199. (John Hopkins University Press: Baltimore, MD.)

Meffe, G. K. (1983). Attempted chemical renovation of an Arizona springbrook for management of the endangered Sonoran topminnow. North American Journal of Fisheries Management 3, 315-321. doi:10.1577/ 1548-8659(1983)3<315:ACROAA >2.0.CO;2

Miller, R. R., Williams, J. D., and Williams, J. E. (1989). Extinctions of North American fishes during the past century. Fisheries 14, 22-38. doi:10.1577/1548-8446(1989)014<0022:EONAFD >2.0.CO;2

Minckley, W. L. (1999). Ecological review and management recommendations for recovery of the endangered Gila topminnow. Great Basin Naturalist 59, 230-244.

Morgan, D. L., Gill, H. S., Maddern, M. G., and Beatty, S. J. (2004). Distribution and impacts of introduced freshwater fishes in Western Australia. New Zealand Journal of Marine and Freshwater Research 38 , $511-523$. 
Ng, P. K. L., and Tan, H. H. (1997). Freshwater fishes of southeast Asia: potential for the aquarium fish trade and conservation issues. Aquarium Sciences and Conservation 1, 79-90. doi:10.1023/A:1018335617835

Pearson, B. (1999). An experience with the redfin blue-eye. Australia and New Guinea Fish Association News 42, 1-4.

Pierce, B. E., Young, M., and Sim, T. (2004). South Australia's Flinders Ranges fishes. Fishes of Sahul 18, 26-41.

Ponder, W. F. (2004). Endemic aquatic macroinvertebrates of artesian springs of the Great Artesian Basin - progress and future directions. Records of the South Australian Museum 7, 101-110.

Ponder, W. F., and Clark, G. A. (1990). A radiation of hydrobiid snails in threatened artesian springs in western Queensland. Records of the Australian Museum 42, 301-363.

Robinson, R. (2004). Scaturiginichthys vermeilipinnis - propagating by egg picking. Australia and New Guinea Fish Association News 20, 3.

Tappin, A. R. (1995a). Redfinned blue-eye (breeding report). Fishes of Sahul 9, 430-432.

Tappin, A. R. (1995b). The red-finned blue-eye: Scaturiginichthys vermeilipinnis. Regenbogenfisch 2, 25-27.

Tappin, A. R. (1999). Scaturiginichthys vermeilipinnis. Some further observations. Australia and New Guinea Fish Association Bulletin 42, 11.

Taylor, F. R., Gillman, L. A., and Pedretti, J. W. (1989). Impact of cattle on two isolated fish populations in Pahranagat Valley, Nevada. Great Basin Naturalist 49, 491-495.

Thresher, R., and Bax, N. (2003). The science of producing daughterless technology; possibilities for population control using daughterless technology; maximising the impact of carp control. In 'Proceedings of National Carp Control Workshop, 5-6 March 2003'. pp. 19-24. (CSIRO Discovery and Co-operative Research Centre for Pest Animal Control: Canberra.)

Unmack, P. (1992). Further observations on the redfinned blue eye's conservation status. Australia and New Guinea Fish Association Bulletin 12, $8-9$.
Unmack, P., and Brumley, C. (1991). Initial observations on spawning and conservation status of redfinned blue-eye (Scaturiginichthys vermeilipinnis). Fishes of Sahul 6, 282-284.

Unmack, P. J., and Paras, G. J. (1995). Galaxiella pusilla: around Melbourne, going, going, nearly gone. Fishes of Sahul 9, 398-400.

Wager, R. (1994). The distribution of two endangered fish in Queensland. Endangered Species Unit Project Number 276. Final Report Part B: The distribution and status of the red-finned blue-eye. Australian Nature Conservation Agency, Canberra.

Wager, R. (1995). Recovery Plan for Queensland artesian spring fishes. Report for the Australian Nature Conservation Agency, Canberra.

Wager, R. (1998). Progress report to the Australian Nature Conservation Agency in relation to consultancy services for the Artesian Spring Fishes Recovery Plan in Queensland (1995/96) (July 1997 to March 1998). ANCA Project No. 529.

Wager, R., and Unmack, P. J. (2000). 'Fishes of the Lake Eyre Catchment of central Australia.' (Department of Primary Industries and Queensland Fisheries Service: Brisbane.)

Wager, R. N. E., and Unmack, P. J. (2004). Threatened fishes of the world: Scaturiginichthys vermeilipinnis (Ivanstoff, Unmack, Saeed and Crowley 1991) (Pseudomugilidae). Environmental Biology of Fishes 70, 330. doi:10.1023/B:EBFI.0000035508.38721.81

Walker, G. (2005). Red-finned blue-eye Scaturiginichthys vermeilipinnis. The next generation. Australia and New Guinea Fish Association News 21, $1-4$.

Water Management and Use Group (2005). 'Great Artesian Basin draft water resource plan.' (Queensland Department of Natural Resources and Mines: Brisbane.)

Manuscript received 13 July 2006, accepted 14 March 2006 